Gynecol. obstet. Invest. 1981;12:I-V

\title{
Contents, Vol. 12, 1981
}

\section{No.l}

Original Paper

Development and Classification of Parovarian Cysts. An Ultrastructural Study

Stenbäck, F.; Kauppila, A

Effects of Angiotensin II Analog on Blood Pressure, Renin and Aldosterone in Women on Oral Contraceptives and Toxemia

Saruta, T.; Nakamura, R.; Nagahama, S.; Suzuki, H.; Kondo, K

Renal Damage following Transplantations of Heterologous Placental Tissue

Toder, V.; Blank, M; Fein, A.; Nebel, L

Preoperative Administration of Prostaglandin to Avoid Dilatation-Induced Damage in First-

Trimester

Pregnancy Terminations

Heinzl, S.; Andor, J 29

Radioimmunoassay Procedure of Serum Myoglobin in Case of a Long-Term Tocolysis with ß-

Sympatho-

mimetics

Meinen, K 37

A Simple and Rapid Method in the Determination of Urinary Estrogen to Creatinine Ratio during Pregnancy

Yamane, T.; Kawamoto, $\mathrm{H} \quad 44$

Book Review 55

No. 2

Original Paper

Endometrioid Ovarian Tumors: Morphology and Relation to Other Endometrial Conditions

Stenbäck, F.; Kauppila, A 57

New Thermal Method for Evaluating Vaginal Blood Flow

Frisinger, J.E.; Abrams, R.M.; Graichen, H.; Cassin, S 71

Demonstration of Plasma Human Chorionic Gonadotropin ß-Subunit during Pregnancy Using

LH-hCG

Receptors from Immature Porcine Testis

Mputu, L.; Thomas, K; Pirens, G.; Frankenne, F.; Hennen, G

Serum Estriol Levels during ß-Receptor Agonist Infusion in the Third Trimester of Pregnancy

Bremme, K; Eneroth, P 93

Plasma Steroids and Human Placental Lactogen Level Changes in Late Pregnancy in Association with

Intravenous Ritodrine Administration

Schreyer, P.; Zer, Y.; Ariely, S.; Zer, T.; Caspi, E 99

IV

Contents 
Current Investigation

A Newly Recognized Cause of Low Urinary Estriol in Pregnancy: Multiple Sulfatase Deficiency of the

Fetus

Steinmann, B.; Mieth, D.; Gitzelmann, R 107

Book Review 110

No. 3

Original Paper

Human Fetal Membranes: Investigations on Membrane Potentials and Membrane 24Na

Permeability in

vitro and the Possible Involvement of Acetylcholine

Welsch, F 113

Constriction of Human Umbilical Artery Induced by Local Anesthetics

Silva de Sá, M.F.; Meirelles, R.S.; Franco, J.G., Jr.; Rodrigues, R 123

Effects of Crude and Purified Human Chorionic Gonadotropin on Lymphocyte Response

Schmidt, W.; Merz, W.E.; Lenhard, V.; Kubli, F 132

Studies on Blood Coagulation and Fibrinolysis in Pregnancy, during Delivery and in the

Puerperium.

I. Normal Condition

Hellgren, M.; Blombäck, M 141

Effects of Vitamin D Supplementation in Pregnancy

Marya, R.K.; Rathee, S.; Lata, V.; Mudgil, S. . 155

Plasma Urate Measurements and Fetal Outcome in Preeclampsia

Schuster, E.; Weppelmann, B 162

Announcements 168

Erratum $\quad 168$

No. 4

Original Paper

Endometrial Carcinoma: Histopathology, Survival, and Exogenous Estrogens

Smith, D.C.; Prentice, R.L.; Bauermeister, D.E 169

Effect of Copper Intrauterine Devices on the Chemical Composition of Rabbit Oviduct Fluid

David, A.; Levinsky, H.; Allalouf, D.; Feller, N 180

Effects of Glycine on Serum Gonadotropins and Estradiol and on Concentrations of Free Amino

Acids in

the Middle Hypothalamus in Female Rats

Morishita, H.; Hashimoto, T.; Kishi, K..; Nakago, K.; Mitani, H.; Tomioka, M.; Kuroiwa, S.;

Miyauchi, Y 187

Comparison of Oral Prostaglandin E2 and Intravenous Oxytocin for Induction of Labour

Lichtenegger, W.; Lahousen, M.; Kraemer, H 197

HCG, Progesterone and 17-Beta-Estradiol Levels during Extra-Amniotically Induced Early

Abortion by a

New Prostaglandin Derivative (Sulprostone)

Nilsson, S.; Zador, G.; Nygren, K.-G.; Wide, L 203

Blood Pressure and Pressor Response to Angiotensin II during Pregnancy and Nursing in the Rabbit

Katz, M.; Creasy, R.K 211 


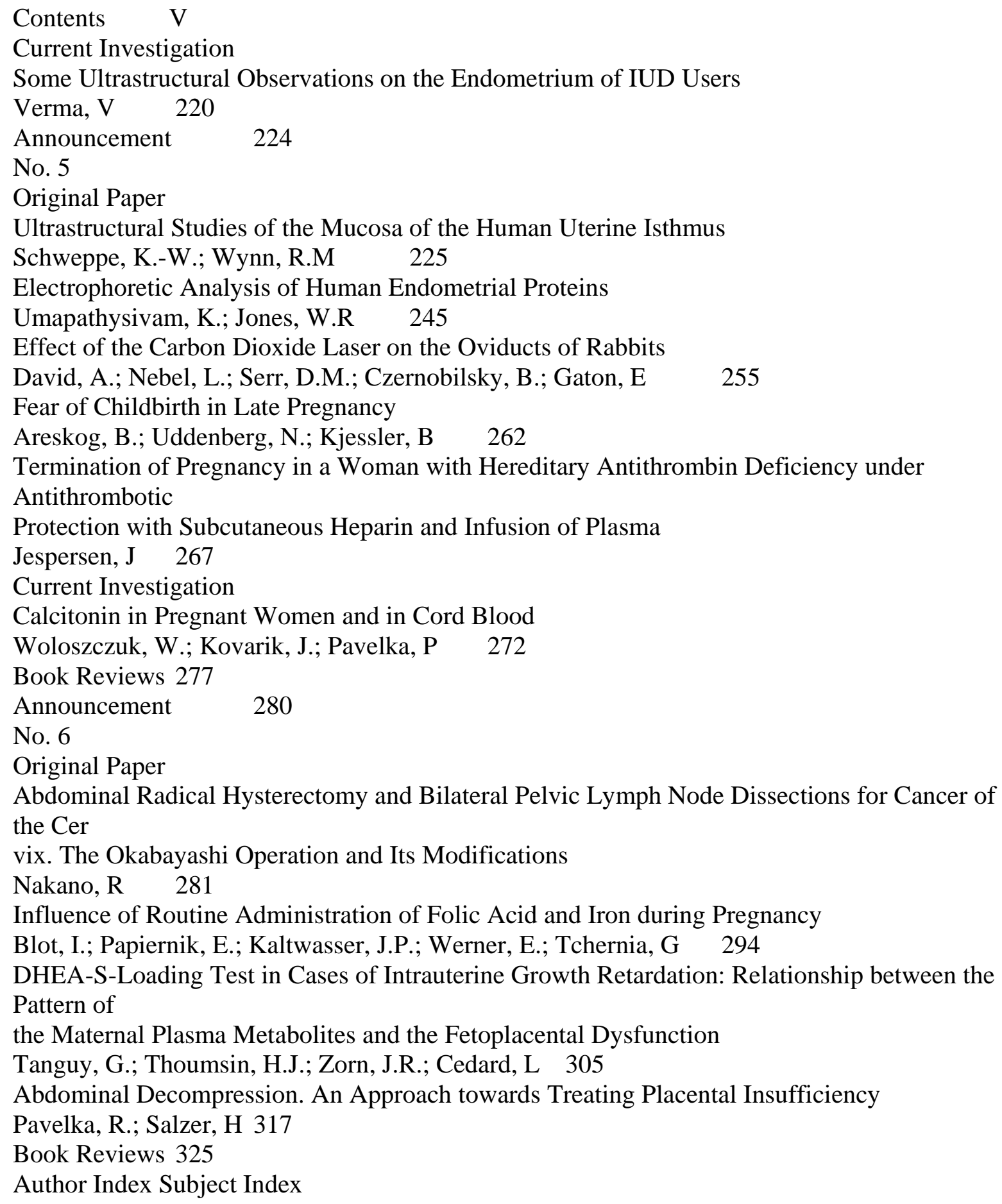

